\title{
絶縁ゲートバイポーラトランジスタ [制定］（JEC-2405-2000）
}

パワーエレクトロニクス標淮化委員会 委員長 松瀬貢規
電力用トランジスタ標準特別委員会 委員長 川上 明
パワーエレクトロニクス標準化委員会では, 半導体電 力変換装置, 半導体バルブデバイスとして使用されるパ ワー半導体デバイスなどのパワーエレクトロニクス関連 製品・システムの規格の整備, IEC 規格との整合化な どの課題に取り組んでいる。このたび，JEC-24052000 (絶緑ゲートバイポーラトランジスタ) を制定した のでその概要を紹介する。

バイポーラパワートランジスタ，絶縁ゲートバイポー ラトランジスタ (IGBT) などのパワートランジスタは 大容量化, 高機能化が進み, 半導体電力変換装置に広く 適用されている。汎用インバータ, 家電品などのインバ ー夕は,すべてパワートランジスタを使用しているとい ってよい。このため, パワートランジスタの標準化が急 務となっていた。

このような現状からパワーエレクトロニクス標準化委 員会では電力用トランジスタ標準特別委員会を設置し, まずJEC-2404-1999 (バイポーラパワートランジスタ) を制定した。引き続きIGBT の規格について 1997 年 (平成 9 年) 10 月, 調査に着手し, 慎重審議の結果, 2000 年 6 月に成案を得, 2000 年 9 月に電気規格調查会 委員総会の承認を経て本規格を制定した。

本規格の主な内容は，JEC-2404-1999に準じている。 以下ではIGBT 特有の内容を中心に概要を説明する。

（1）IGBT に関して IECでは 1998 年に IEC 60747-9 が発行されている。本規格はこの IEC 規格に整合させ， 主として変換装置に，オンオフ制御バルブデバイスとし て適用されるIGBT を適用対象として規格化した。
（2）“ラッチング動作”，“しきい值電圧”, “ゲート電 荷量”などの IGBT 関係の用語を追加し，関連用語を 電気専門用語集 No.9（パワーエレクトロニクス）に基 づいて定義した。

特に“入力容量”などの “容量”は, capacityの意 味の “容量”と紛らわしいため, “入力 [静電] 容量” などとして capacitance の意味であることが必要に応じ て明確に分かるようにした。

（３）“定格ゲート静電耐量”, “最大しきい值電圧”な どの IGBT 関係の定格・特性を追加し, 電気的定格・ 温度定格・機械的定格, 抢よび電気的特性・熱的特性そ れぞれについて規定する項目を説明した。

（4）IGBT の試験項目を形式試験・常規試験に分け て示した。“ゲート静電耐量試験”, “入力容量試験”な どIGBT 関係の試験を追加し，各試験項目について試 験回路も加えて試験方法を説明した。スイッチング試験 ではIGBT がパワー回路のスイッチングに利用される ことから，誘導負荷スイッチング試験についても規定し た。

パワーエレクトロニクス標準化委員会では現在, 可変 速駆動システム標準特別委員会および半導体無停電電源 システム標準特別委員会において可変速駆動システムお よびUPSの JEC 規格の制定・改訂を進めている。パ ワー半導体デバイスでは新たに MOS 形電界効果パワー トランジスタ（パワーMOSFET）の JEC 規格を制定 するべく調査を開始する予定である。 